\title{
DIVERSIFIKASI MANFAAT RIMPANG TEMULAWAK SEBAGAI KOMPONEN AKTIF TERHADAP BAKTERI STREPTOCOCCUS MUTANS PADA PEMBUATAN PERMEN KESEHATAN
}

\section{DIVERSIFICATION OF GINGER RHIZOME AS ACTIVE COMPONENTS ON STREPTOCOCCUS MUTANTS BACTERIA IN MAKING OF HEALTH CANDIES}

\author{
Medan Yumas \\ Balai Besar Industri Hasil Perkebunan (BBIHP) \\ Jl. Racing Centre No. 28 Makassar \\ Email : medan.yumas@yahoo.com
}

Naskah diterima 29 Juli 2011, disetujui 20 Februari 2012

\begin{abstract}
ABSTRAK
Penelitian diversifikasi manfaat rimpang temulawak sebagai komponen aktif terhadap bakteri Streptococcus mutans pada pembuatan permen kesehatan mulut telah dilakukan. Tujuan penelitian adalah menghasilkan permen kesehatan mulut dengan kandungan minyak temulawak sebagai komponen aktifnya, yang berfungsi sebagai anti bakteri, anti inflamasi, dan dapat menetralkan asam di dalam mulut. Minyak temulawak mengandung komponen aktif xanthorrizol. Hasil penelitian menunjukkan bahwa konsentrasi hambat minimum terhadap bakteri Streptococcus mutans adalah $0,25 \%$ bersifat bakteriostatik dan konsentrasi bunuh minimum adalah $0,40 \%$ bersifat bakterisid. Penambahan minyak temulawak pada pembuatan permen kesehatan mulut dilakukan dengan variasi konsentrasi $0,40 \% ; 0,55 \% ; 0,70 \% ; 0,85 \%$ dan $1 \%$ (b/b). Permen kesehatan mulut dengan konsentrasi penambahan minyak temulawak 0,85\% mampu membunuh bakteri Streptococcus mutans dalam waktu 1 menit dan memiliki diameter zona daya hambat $15,89 \mathrm{~mm}$ dan jenis permen kesehatan tersebut yang paling disukai oleh panelis.
\end{abstract}

Kata kunci: ekstraksi, komponen aktif, minyak temulawak, permen kesehatan eksperimen, Streptococcus mutans.

\begin{abstract}
The research to utilization of ginger rhizome as active component on Streptococcus mutants in the manufacture of oral health candy have been carried out. The aim of this research is to produce health candies with containing the main active component of ginger oil. These components can serve as anti bacterial, anti inflammatory, and can neutralize acid in the mouth. Ginger oil contain main active components known as xanthorrizol. The result showed that the minimum inhibitory concentration again is Streptococcus mutants was $0,25 \%$, (bacteriostatic) and minimum kill concentration was $0,40 \%$ (bakterisid). The addition of ginger oil in the manufacture of health candies was done by varying the concentration $0,40 \%, 0,55 \%, 0,70 \%, 0,85 \%$ and $1 \%$ (b/b). Candy health with the addition of $0,85 \%$ concentration of ginger oil can kill the bacteria Streptococcus mutants in one minute and have power zone of inhibition 15,89 $\mathrm{mm}$. This type of candy is the most preferred health by panelist.
\end{abstract}

Keywords : extraction, ginger oil, health candy experiment, the active componen. 


\section{PENDAHULUAN}

T Temulawak dikenal sebagai tanaman obat tradisional yang banyak tersebar di berbagai tempat di Indonesia.Komponen utama minyak temulawak adalah a - curcumen, xanthorrizol, farnezol, germacrone, camphor, zingiberene, camphene, cineole, dan lain-lain (Suryatmi, 2008).

\section{Temulawak}

(Curcuma

xanthorriza, Roxb) merupakan salah satu herbal asal Indonesia, dan diantara jenis temu merupakan jenis yang paling banyak digunakan sebagai obat tradisional. Temulawak dapat digunakan sebagai obat utama (remediumcardinale), bahan obat penunjang (remediumadjuvans), pemberi warna, penambah aroma, makanan, minuman penyegar, bahan baku industri seperti kosmetika. Sebagai obat tradisional mulai banyak digunakan dalam bentuk tunggal atau campuran, dan berkhasiat untuk laktagoga, kolagoga, anti inflamasi, tonikum, diuretik,antitumor, fungistatik, bakteriostatik, pengobatan penyakit jantung dan lever.

Minyak temulawak merupakan minyak yang diperoleh dari tanaman temulawak melalui proses ekstraksi. Ekstrak minyak temulawak mengandung 32 komponen senyawa turunan monoterpen dan seskuiterpen yang secara umum bersifat meningkatkan produksi getah empedu dan bersifat anti inflamasi (Sidik, 2006). Menurut Purnomowati (2009) mengatakan bahwa kandungan utama minyak atsiri temulawak adalah xanthorrizol (21\%), germakren, isofuranogermakren, trisiklin, alfa-aromadendren. Hasil penelitian Hwang (2000) menunjukkan bahwa xanthorrhizol dalam temulawak memiliki aktifitas anti kariogenik, anti inflamasi dan mampu membasmi bakteri patogen penyebab karang gigi yaitu bakteri jenis Streptococcus mutans.

Permen kesehatan pada umumnya mengandung beberapa komponen aktif dari bahan kimia misalnya triclosan $0,3 \%$, eter polivinil metal 25, asam maleat, dan seng klorida. Bahan-bahan komponen aktif tersebut mempunyai fungsi mencegah infeksi, namun dapat menyebabkan kerusakan jaringan di dalam rongga mulut. Oleh karena itu beberapa penelitian, sementara mempertimbangkan untuk mengembangkan bahan anti plak alternatif dari bahan alami, perhatian ke obat-obatan yang dibuat dari bahan alami cukup luas, misalnya penelitian yang telah dilakukan oleh Sartini, dkk (2007) dari limbah kulit buah kakao dan Amos (2009) dari gambir. Bila terjadi pembengkakan, hal tersebut disebabkan bahan aktif dalam permen kesehatan, pasta gigi, dan obat kumur diabsorbsi melalui dinding bagian dalam mukosa, dimana absorbsi itu cukup efisien di atas 90\% (Allen D, 2004). Oleh karena itu beberapa penelitian sementara ini mempertimbangkan pengembangan bahan alternatif anti bakteri, anti inflamasi, dan antiplak sebagai komponen aktif pada pasta gigi yang bersumber dari bahan alami bukan bahan kimia. Komponen aktif yang terkandung dalam berbagai jenis ekstrak tumbuhan diketahui dapat menghambat beberapa mikroba patogen maupun perusak makanan. Zat aktif tersebut dapat berasal dari bagian tumbuhan seperti biji, buah, rimpang, batang, daun, dan umbi (Ardiansyah, 2007).

Tujuan penelitian adalah menghasilkan permen kesehatan dengan kandungan minyak temulawak sebagai komponen aktif yang berfungsi sebagai anti bakteri. Dan merupakan bahan alternatif zat anti bakteri yang berasal dari bahan alami sebagai pengganti bahan kimia yang tidak direkomendasikan lagi karena akan menimbulkan efek samping bagi kesehatan misalnyatriclosan $0,3 \%$, eter polivinil metal 25 , asam maleat, serta kopolimer seperti seng klorida. Hasil penelitian ini diharapkan dapat meningkatkan diversifikasi produk pemanfaatan temulawak yang 
peruntukkannya tidak hanya pada makanan dan minuman saja akan tetapi dapat dikembangkan menjadi produk jenis lain di bidang kesehatan dan farmasi.

\section{BAHAN DAN METODE}

\section{Bahan dan Peralatan}

Bahan yang digunakan dalam penelitian ini terdiri dari bahan baku dan bahan kimia. Bahan baku yang digunakan adalah rimpang temulawak (Curcuma xanthorrizol Roxb), Aquadest, Mentol 96\% (berdasarkan gradasi polaritas), Pepermin oil, Glukosa, dan Sukrosa.Bahan kimia yang digunakan adalah metanol, kalsium klorida, dan etilasetat.

Peralatan yang digunakan pada penelitian ini adalah kain saring, pisau stainlessteel, talenan, panci stainlessteel, aluminium foil, kondensor tegak dan leebig, gelas ukur (pyrex), erlenmeyer $300 \mathrm{ml}, 500 \mathrm{ml}$, dan 1 liter (pyrex), gelas kimia (pyrex), corong kaca (pyrex), cawan petri, pipet volume $25 \mathrm{ml}$ (pyrex), cawan porselin, labu alas bulat, blender, $\mathrm{pH}$ meter, timbangan dengan kapasitas $5 \mathrm{~kg}$, mixer; viscometer brookfield dengan model RV, spektrofotometer FTIR Merek Perkin Elmer; neraca analitik (Sartorius), dan termometer air raksa $\left(0-100^{\circ} \mathrm{C}\right)$.

\section{Metode}

Metode yang digunakan dalam penelitian pembuatan permen kesehatan terdiri dari 6 tahapan yaitu:

\section{Ekstraksi RimpangTemulawak}

Ekstraksi rimpangtemulawak untuk memperoleh minyak temulawak dilakukan dengan metode maserasi.Temulawak kering di blender hingga halus dan ditimbang sebanyak 1 kg.Temulawak ditempatkan dalam wadah (gelas kimia) dan ditambahkan pelarut metanol $96 \%$ dengan perbandingan (1:3) sambil diaduk dan disimpan selama satu malam. Penggunaan metanol $96 \%$ sebagai pelarut didasarkan pada perbedaan gradasi polaritas. Temulawak yang telah direndam, disaring ke dalam wadah bersih menjadi filtrat 1 , residu dimasukkan kembali ke gelas kimia dan ditambahkan lagi metanol $96 \%$ diaduk dan disimpan lagi selama satu malam. Hasilnya kembali disaring menjadi filtrat 2, filtrat 1 dan 2 digabungkan, kemudian dievaporasi dengan rotavapor pada tekanan rendah dan suhu $50^{\circ} \mathrm{C}$ untuk menguapkan metanol. Residu yang berupa minyak dikumpulkan dan dimurnikan. Skema proses ekstraksi secara maserasi dapat dilihat pada Gambar 1.

\section{Proses Pemisahan}

Proses pemisahan terhadap emulsi minyak yang diperoleh dari hasil ekstraksi secara maserasi dilakukan dengan cara mengekstrak kembali dengan menggunakan pelarut etilasetat. Campuran tersebut diaduk, kemudian disimpan pada suhu ruang sampai membentuk dua lapisan (fase atas dan fase bawah). Apabila telah terbentuk dua lapisan dilakukan pemisahan dengan corong pisah, lapisan atas I dari campuran tersebut diambil dan lapisan bawah ditambah lagi dengan etilasetat untuk memperoleh lapisan atas II. Lapisan atas I dan lapisan atas II dicampur dan di distilasi fraksionasi pada tekanan rendah untuk menguapkan etilasetat, selanjutnya dilakukan penambahan $\mathrm{CaCl}_{2}$ untuk menyerap air yang masih tersisa sehingga diperoleh minyak temulawak yang sudah murni.Minyak temulawak diamati SpectrofotometerFTIR untuk mengetahui gugus fungsi yang terkandung di dalam minyak temulawak.

\section{Konsentrasi Hambat Minimal dan Uji Zona Daya HambatAntimikroba}

Penentuan konsentrasi hambat minimal dari ekstrak rimpang temulawak dipilih konsentrasi yang terendah yaitu : konsentrasi $\quad 0,1 \%$; $0,25 \% ; \quad 0,40 \%$; 
$0,55 \% ; \quad 0,70 \% ; \quad 0,85 \% ;$ dan $1 \% \mathrm{~b} / \mathrm{b}$ terhadap bakteri Streptococcus mutans dilakukan dengan metode pengenceran sesuai metode National Committee for Clinical Laboratoris Standards (NCCLS, 1985), cit Oewen (1987). Konsentrasi hambat minimum ditentukan oleh tabung yang berisi konsentrasi obat terendah yang masih menghambat pertumbuhan kuman (perbenihan tetap jernih). Uji zona daya hambat ditandai dengan daerah bening sekitar pencandang.

\section{Pembuatan Permen}

Pembuatan permen kesehatan dengan komponen aktif dari ekstraksi rimpang temulawak diawali dengan menimbang sukrosa, glukosa, peppermin oil, menthol, air dan minyak temulawak. Gula pasir dilarutkan ke dalam air yang telah didihkan hingga suhu $100^{\circ} \mathrm{C}$ setelah itu dilanjutkan pemanasan hingga $110^{\circ} \mathrm{C}$ dan setelah mencapai suhu tersebut ditambahkan glukosa dan terus dilanjutkan pemanasan hingga $140^{\circ} \mathrm{C}$. Pada saat pemanasan telah mencapai suhu yang ditentukan, pemanasan dihentikan dan segera ditambahkan peppermint oil, menthol, dan minyak temulawakdengan konsentrasi yang ditambahkan mengacu pada hasil tahap 3 yang dilihat dari diameter zona daya hambat anti bakteri yang besar, sambil diaduk hingga merata. Campuran dimasukkan ke dalam cetakan dan segera didinginkan.

\section{Uji Aktifitas Anti Bakteri Permen Kesehatan}

Uji aktifitas anti bakteri dilakukan setelah dalam bentuk permen kesehatan.Uji aktifitas atau daya hambat anti bakteri menggunakan metode Pratten et al (1998) dan total mikroba dilakukan dengan menggunakan metode hitungan cawan (Fardiaz, 1992).

\section{Uji Cita Rasa Permen Kesehatan}

Penilaian terhadap permen kesehatan dilakukan oleh 15 orang panelis, dengan cara memberikan permen kesehatan eksperimen untuk dicicipi berdasarkan lama waktu keberadaan permen kesehatan eksperimen di dalam mulut. Penilaian panelis dituliskan dalam bentuk skala hedonik 1-5 dengan tingkat kesukaan yang semakin meningkat seiring semakin tingginya angka skala ( $1=$ sangat tidak suka; 2 = tidak suka; $3=$ netral; 4 = suka; dan 5 = sangat suka). Analisis data dilakukan secara statistik menggunakan analisis ragam, dan bila terdapat perbedaan yang nyata dilanjutkan dengan uji BNJ (Sugandi dan Sugiarto, 1993). 


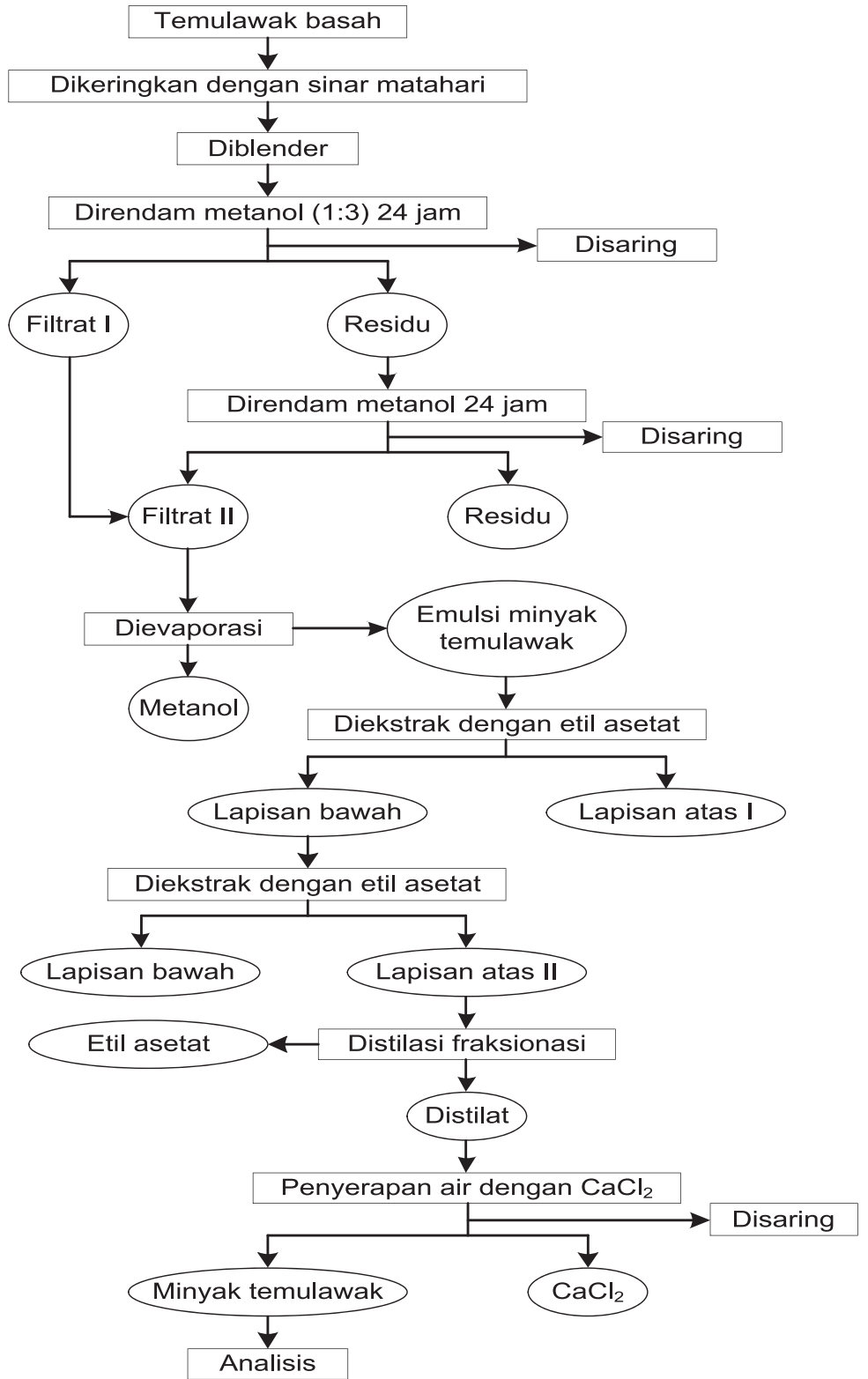

Gambar 1. Diagram Alir Proses Ekstraksi Rimpang Temulawak Secara Maserasi

\section{HASIL DAN PEMBAHASAN}

\section{Ekstraksi Minyak Dari Rimpang Temulawak}

Ekstraksi temulawak secara maserasi dilakukan dengan menggunakan pelarut metanol 96\%. Proses ekstraksi ini adalah untuk memisahkan minyak dari rimpang temulawak dengan kandungan komponen aktif yang dapat dijadikan sebagai zat aditif pada pembuatan permen kesehatan mulut. Metanol dapat melarutkan komponen senyawa aktif yang terdapat didalam temulawak berupa senyawa fenolik, dimana hasil ekstraksi tersebut banyak mengandung komponen senyawa fenolik. Pemilihan metode maserasi dikarenakan senyawa komponen aktif rentan terhadap panas sehingga tidak bagus menggunakan metode soxhlet. Hal ini didukung oleh penelitian Cheong, et.al (2005) bahwa dengan menggunakan metode soxhlet konsentrasi senyawa komponen aktif mengalami penurunan dibandingkan dengan metode maserasi. Rendemen minyak yang diperoleh secara maserasi sebesar 67,4 gram atau persentase hasil (yield) sekitar $6,74 \%$ atas dasar 
berat dari $1 \mathrm{~kg}$ temulawak kering. Rendeman minyak yang diperoleh dengan metode ekstraksi secara maserasi, jauh lebih banyak ketimbang jenis metode ekstraksi menggunakan soxhlet. Hal ini disebabkan karena secara maserasi dilakukan proses perendaman selama satu malam dalam suasana dingin atau suhu yang agak rendah sekitar $60^{\circ} \mathrm{C}-70^{\circ} \mathrm{C}$, sehingga jumlah minyak yang terikut jauh lebih banyak ketimbang menggunakan metodelain. Hal ini sejalan dengan hasil penelitian yang dilakukan oleh Cheong, et.al., (2005) dan Setiyowati (2007) yang menunjukkan bahwa pada metode maserasi, proses ekstraksi terjadi dalam suasana dingin atau bersifat dingin dan interaksi antara zat terlarut dan pelarut terjadi secara alamiah, sehingga membutuhkan waktu yang lebih lama untuk mencapai kesetimbangan zat terlarut diantara fasa pelarut dengan zat padat.Sedangkan pada metode ekstraksi secara reflux rendemen minyak yang diperoleh lebih rendah karena proses ekstrasi tersebut terjadi dalam suasana panas atau bersifat panas sehingga pada saat terjadi proses pemanasan, pati yang terkandung dalam temulawak terdekomposisi dan menutupi pori-pori butiran temulawak.

\section{Penentuan Konsentrasi Hambat Minimal dan Zona Daya Hambat}

Penentuan konsentrasi hambat minimum, konsentrasi bunuh minimum, dan zona diameter hambat terhadap bakteri Streptococcus mutans, hasilnya dapat dilihat pada Tabel 1 dan Tabel 2 di bawah ini.

Tabel 1. Kadar hambat minimum dan kadar bunuh minimum hasil ekstrak rimpang temulawak terhadap Streptococcusmutans

\begin{tabular}{c|c|c|c|c|c|c|c|c}
\hline \multicolumn{10}{c}{ Perlakuan Kontrol } \\
\hline $0,1 \%$ & $0,25 \%$ & $0,40 \%$ & $0,55 \%$ & $0,70 \%$ & $0,85 \%$ & $1 \%$ & $(-)$ & $(+)$ \\
\hline $\begin{array}{c}\text { Jernih } \\
(+)\end{array}$ & $\begin{array}{c}\text { Jernih } \\
(+)\end{array}$ & $\begin{array}{c}\text { Keruh } \\
(-)\end{array}$ & $\begin{array}{c}\text { Keruh } \\
(-)\end{array}$ & $\begin{array}{c}\text { Keruh } \\
(-)\end{array}$ & $\begin{array}{c}\text { Keruh } \\
(-)\end{array}$ & $\begin{array}{c}\text { Keruh } \\
(-)\end{array}$ & $\begin{array}{c}\text { Jernih } \\
(+)\end{array}$ & $\begin{array}{c}\text { Keruh } \\
(-)\end{array}$ \\
\hline $\begin{array}{c}\text { Keruh } \\
(-)\end{array}$ & $\begin{array}{c}\text { Keruh } \\
(+)\end{array}$ & $\begin{array}{c}\text { Keruh } \\
(-)\end{array}$ & $\begin{array}{c}\text { Keruh } \\
(-)\end{array}$ & $\begin{array}{c}\text { Keruh } \\
(-)\end{array}$ & $\begin{array}{c}\text { Keruh } \\
(-)\end{array}$ & $\begin{array}{c}\text { Keruh } \\
(-)\end{array}$ & $\begin{array}{c}\text { Jernih } \\
(+)\end{array}$ & $\begin{array}{c}\text { Keruh } \\
(-)\end{array}$ \\
\hline $\begin{array}{c}\text { Jernih } \\
(+)\end{array}$ & $\begin{array}{c}\text { Keruh } \\
(+)\end{array}$ & $\begin{array}{c}\text { Keruh } \\
(-)\end{array}$ & $\begin{array}{c}\text { Keruh } \\
(-)\end{array}$ & $\begin{array}{c}\text { Keruh } \\
(-)\end{array}$ & $\begin{array}{c}\text { Keruh } \\
(-)\end{array}$ & $\begin{array}{c}\text { Keruh } \\
(-)\end{array}$ & $\begin{array}{c}\text { Jernih } \\
(+)\end{array}$ & $\begin{array}{c}\text { Keruh } \\
(-)\end{array}$ \\
\hline $\begin{array}{c}\text { Jernih } \\
(+)\end{array}$ & $\begin{array}{c}\text { Keruh } \\
(-)\end{array}$ & $\begin{array}{c}\text { Keruh } \\
(-)\end{array}$ & $\begin{array}{c}\text { Keruh } \\
(-)\end{array}$ & $\begin{array}{c}\text { Keruh } \\
(-)\end{array}$ & $\begin{array}{c}\text { Keruh } \\
(-)\end{array}$ & $\begin{array}{c}\text { Keruh } \\
(-)\end{array}$ & $\begin{array}{c}\text { Jernih } \\
(+)\end{array}$ & $\begin{array}{c}\text { Keruh } \\
(-)\end{array}$ \\
\hline $\begin{array}{c}\text { Jernih } \\
(+)\end{array}$ & $\begin{array}{c}\text { Keruh } \\
(+)\end{array}$ & $\begin{array}{c}\text { Keruh } \\
(-)\end{array}$ & $\begin{array}{c}\text { Keruh } \\
(-)\end{array}$ & $\begin{array}{c}\text { Keruh } \\
(-)\end{array}$ & $\begin{array}{c}\text { Keruh } \\
(-)\end{array}$ & $\begin{array}{c}\text { Keruh } \\
(-)\end{array}$ & $\begin{array}{c}\text { Jernih } \\
(+)\end{array}$ & $\begin{array}{c}\text { Keruh } \\
(-)\end{array}$ \\
\hline
\end{tabular}

Keterangan :

$(+)=$ terdapat pertumbuhan bakteri

$(-)=$ tidak terdapat pertumbuhan bakteri

Pada Tabel 1, tersebut diatas menunjukan bahwa tidak terdapat kekeruhan pada konsentrasi $0,1 \%$ dan kontrol negatif, sedangkan pada konsentrasi $0,25 \%$ ke atas dan kontrol positif menunjukan kekeruhan pada suspense bakteri dan ekstrak rimpang temulawak. Hasil uji menunjukkan bahwa efek penghambatan pertumbuhan yang bermakna setelah dibandingkan kontrol positif terdapat

pada konsentrasi ekstrak rimpang temulawak (minyak temulawak) 1\%; $0,85 \% ; \quad 0,70 \% ; \quad 0,55 \% ; \quad 0,40 \%$; dan $0,25 \%$, dengan demikian konsentrasi hambat minimum ekstrak rimpang temulawak (minyak temulawak) pada penelitian ini adalah $0,25 \%$. Walaupun terjadi penghambatan pertumbuhan bakteri pada konsentrasi $0,25 \%$ namun konsentrasi tersebut tidak menjadi konsentrasi bunuh minimum terhadap 
bakteri Streptococcus mutans, karena pada konsentrasi tersebut aktivitas pertumbuhan bakteri Streptococcus mutans masih terjadi. Karena itu ekstrat rimpang temulawak (minyak temulawak) pada konsentrasi $0,25 \%$ bersifat bakteriostatik. Tabel 1 terlihat bahwa pada konsentrasi $0,40 \%$ pertumbuhan bakteri Streptococcus mutans terhenti. Ini menunjukkan bahwa ekstrak temulawak (minyak temulawak) dengan konsentrasi $\quad 0,40 \% \quad$ merupakan konsentrasi bunuh minimum terhadap pertumbuhan bakteri Streptococcus mutans. Pada konsentrasi tersebut aktivitas pertumbuhan bakteri Streptococcus mutansterhenti, sehingga ekstrak rimpang temulawak (minyak temulawak) bersifat bakteriostatik sekaligus bersifat bakterisid pada konsentrasi $0,40 \%$ sampai pada konsentrasi $1,0 \%$.

Tabel 2. Zona diameter hambat dan aktifitas bakteri Streptococcus mutans terhadap minyak temulawak

\begin{tabular}{c|c|c|c|c}
\hline No. & $\begin{array}{c}\text { Konsentrasi Hambat } \\
\text { Minimum dan Konsentrasi } \\
\text { Bunuh Minimum (\%) }\end{array}$ & $\begin{array}{c}\text { Diameter Zona Daya } \\
\text { Hambat (mm) }\end{array}$ & $\begin{array}{c}\text { Waktu } \\
\text { (menit) }\end{array}$ & $\begin{array}{c}\text { Jumlah } \\
\text { Bakteri }\end{array}$ \\
\hline 1 & 0,40 & 13,73 & 2 & 0 \\
\hline 2 & 0,55 & 14,48 & 1 & 0 \\
\hline 3 & 0,70 & 15,64 & 1 & 0 \\
\hline 4 & 0,85 & 15,89 & 0,5 & 0 \\
\hline 5 & 1 & 16,96 & 0,5 & 0 \\
\hline
\end{tabular}

Pada Tabel 2 terlihat bahwa berdasarkan hasil pengujian luas zona bening terhadap konsentrasi minyak temulawak memberikan efek penghambatan terhadap pertumbuhan bakteri bahkan menghentikan aktivitas pertumbuhan bakteri atau membunuh bakteri jenis Streptococcus mutanspada konsentrasi $0,40 \%$ sampai konsentrasi $1,0 \%$. Hal ini sejalan dengan hasil penelitian yang dilakukan oleh Depkes RI (1989), menyatakan bahwa suatu bahan dapat dikatakan memiliki aktivitas antimikroba bila diameter hambatan yang terbentuk adalah lebih dari atau sama dengan $6 \mathrm{~mm}$. Adanya kemampuan sebagai antimikroba dari ekstrak temulawak terhadap bakteri Streptococcus mutans maka diduga senyawa kimia yang ada di dalam ekstrak dan berfungsi sebagai antimikroba adalah golongan polar.

Efek bahan antimikroba tergantung konsentrasinya, umumnya konsentrasi pada tingkat di atas dari konsentrasi hambat minimal mampu menghambat metabolisme bakteri antara lain menghambat produksi asam, menghambat aktifitas protease, dan pertumbuhan bakteri. Ini menunjukkan bahwa semakin tinggi konsentrasi ekstrak uji yang diberikan maka semakin meningkat diameter zona hambat terhadap bakteri. Berdasarkan sifat toksisitas selektif, bakteristatik adalah mikroba yang bersifat menghambat pertumbuhan mikroba, sedangkan yang sifat membunuh mikroba disebut bakterisid (Ayu, 2004). Bakteristatik akan menjadi bakterisid bila kadar atau konsentrasi anti mikrobanya ditingkatkan melebihi konsentrasi hambat minimal dengan waktu penghambatan relatif 0,5 menit sampai satu menit bahkan ada yang di atas satu menit (Tabel 2). Hal ini sejalan hasil penelitian Hwang (2000) yang mengatakan bahwa xanthorrizol memiliki aktivitas antibakteri tertinggi dalam menghambat bakteri jenis Streptococcus, dimana hanya dengan dua mikro gram per milliliter xanthorrizol 
berhasil membasmi Sterptococcus mutans dalam satu menit. Sedangkan menurut hasil penelitian Estrella, dkk (2001) mengatakan bahwa efek mikrobiologikal dan farmakologikal yang dimiliki oleh anti mikroba atau kemoterapeutik mempunyai dua macam efek terhadap organisme yaitu menghambat pertumbuhan dan reproduksi serta menekan inaktifasi seluler. Hasil zona bening pada ekstrak rimpang temulawak (minyak temulawak) pada konsentrasi hambat minimal dapat dilihat pada Gambar 2.

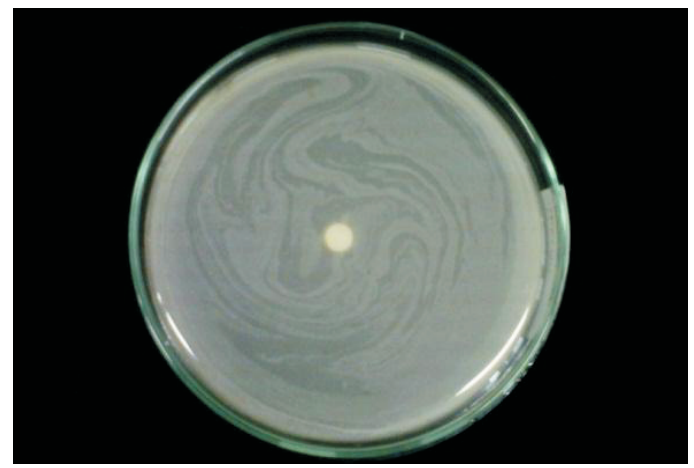

Gambar 2. Zona bening pada ekstrak temulawak anti mikroba terhadap Streptococcus mutan

Tabel 3. Hasil interpretasi spekrum IR minyak temulawak

\begin{tabular}{c|c|c}
\hline No & Peak & Gugus Fungsi \\
\hline 1 & 3386 & $\begin{array}{c}-\mathrm{OH} \text { pada cincin } \\
\text { aromatik }\end{array}$ \\
\hline 2 & 2921,29 & $-\mathrm{CH}_{2}$ - di luar cincin \\
\hline 3 & $2870-2860$ & $\begin{array}{c}-\mathrm{CH}_{3},=\mathrm{C}-\mathrm{CH}_{3} \\
\text { (aromatik) }\end{array}$ \\
\hline 4 & 1583,61 & $\begin{array}{c}-\mathrm{C}-\mathrm{H} \text { aromatik dan } \mathrm{C}-\mathrm{H} \\
\text { alkana }\end{array}$ \\
\hline 5 & 1442,8 & $-\mathrm{OH}$ \\
\hline 6 & 1375,29 & $\mathrm{C}-\mathrm{CH}_{3}$ alifatik \\
\hline 7 & 1262 & $\mathrm{C}=\mathrm{C}$ dan fenol $(-\mathrm{OH})^{-}$ \\
\hline 8 & 1122,61 & $\begin{array}{c}\text { Aromatik tersubtitusi } \\
\mathrm{R}_{2} \mathrm{C}=\mathrm{CHR}\end{array}$ \\
\hline 9 & 821 & ${ }^{\mathrm{CH}_{3}}$ \\
\hline 10 & $639-762$ & $-\mathrm{CH}_{2}-$ atau $\mathrm{RHC}=$ \\
\hline
\end{tabular}

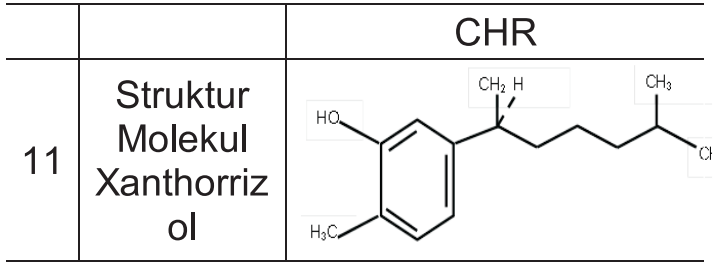

Dari Tabel 3 di atas, hasil analis menggunakan Spektro-fotometer FT-IR terhadap minyak temulawak yang diperoleh dari hasil ekstraksi rimpang temulawak menunjukkan bahwa di dalam minyak temulawak terdapat salah satu komponen aktif yaitu xanthorrizol. Hal ini sejalan hasil penelitian Ma'mun (2006), Suryatmi (2008), dan Hwang (2000) yang mengatakan bahwa komponen kimia yang dominan terdeteksi pada analisis GC-MS dalam sampel bahan baku minyak temulawak yaitu xanthorrizol.

Senyawa komponen aktif ini, mampu mengikat protein mikrotubuli dalam sel kemudian merusak struktur spiddle mitosic dan menghentikan metafasa pembelahan sel bakteri sehingga akan membatasi pertumbuhan bakteri. Xanthorrizol berfungsi mencegah rusaknya email pada gigi atau mencegah timbulnya plak dalam menghambat dan menghentikan aktivitas pertumbuhan bakteri jenis Streptococcus mutans.

Xanthorrizol dapat mengakibatkan kerusakan protein intraseluler asam nukleat dan ion-ion divalen seperti kalsium dan magnesium pada dinding bagian luar sel Streptococcus mutans. Aktivitas bactericidal dari xanthorrizol berperan baik pada perusakan material intraseluler dan penguraian struktur dinding sel, sehingga dianjurkan pemanfaatan xanthorrizol dapat diterapkan di industri sebagai bahan tambahan antikariogenik yang potensial untuk produk-produk oral higienik (Sidik, 2006).

Salah satu mekanisme penghambatan pertumbuhan bakteri oleh suatu antibiotik adalah perusakan membran sel, dimana fosfolipid sebagai komponen utama membran sel dihidrolisis sehingga membran sel tidak 
dapat lagi mempertahankan bentuk sel. Akibatnya terjadi kebocoran membran sel dan bakteri mengalami hambatan pertumbuhan atau bahkan kematian.

Inaktivasi bakteri dapat berupa penghambatan pertumbuhan bakteri(bakteri-ostatik) atau bahkan membunuh bakteri (bakterisidal). Aktivitas penghambatan pertumbuhan atau pembunuhan bakteri dilakukan dengan caramerusak DNA, denaturasi protein, merusak dinding sel atau menghalangi sintesisdinding sel, pemindahan kelompok sulfihidril bebas, serta antagonisme kimiawi (gangguan pada reaksi antara enzim spesifik dengan substratnya). Mekanismenya berupa denaturasi protein, perusakan membran sel, serta pelarutan senyawa lipid dalam sel bakteri (Widiastuti, 2005).

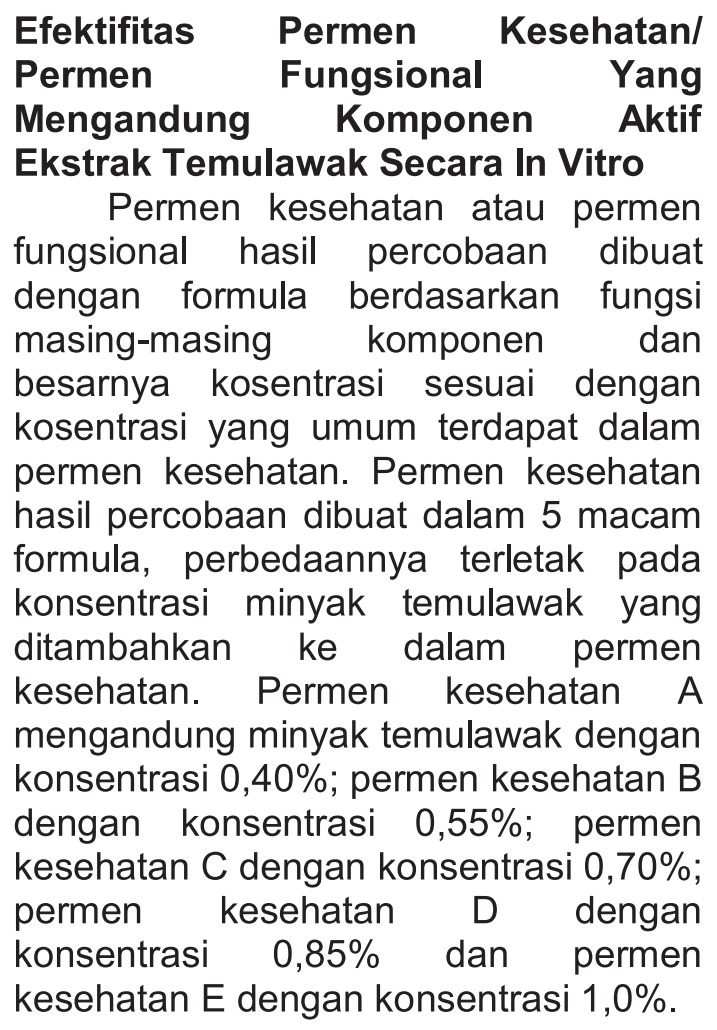

Tabel 4. Hasil uji permen kesehatan hasil percobaan dengan penambahan minyak temulawak sebagai komponen aktif terhadap aktivitas bakteri Streptococcus mutans.

\begin{tabular}{l|c|c|c|c|c|c|c|c}
\hline \multirow{2}{*}{$\begin{array}{c}\text { Jenis Permen } \\
\text { Kesehatan }\end{array}$} & $\begin{array}{c}\text { Jumlah Bakteri } \\
\text { menit }\end{array}$ & $\begin{array}{c}2 \\
\text { menit }\end{array}$ & $\begin{array}{c}3 \\
\text { menit }\end{array}$ & $\begin{array}{c}4 \\
\text { menit }\end{array}$ & $\begin{array}{c}5 \\
\text { menit }\end{array}$ & $\begin{array}{c}6 \\
\text { menit }\end{array}$ & $\begin{array}{c}7 \\
\text { menit }\end{array}$ & $\begin{array}{c}8 \\
\text { menit }\end{array}$ \\
\hline $\mathrm{A}(0,40 \%)$ & 16 & 4 & 0 & 0 & 0 & 0 & 0 & 0 \\
\hline $\mathrm{B}(0,55 \%)$ & 6 & 0 & 0 & 0 & 0 & 0 & 0 & 0 \\
\hline $\mathrm{C}(0,70 \%)$ & 1 & 0 & 0 & 0 & 0 & 0 & 0 & 0 \\
\hline $\mathrm{D}(0,85 \%)$ & 0 & 0 & 0 & 0 & 0 & 0 & 0 & 0 \\
\hline $\mathrm{E}(1 \%)$ & 0 & 0 & 0 & 0 & 0 & 0 & 0 & 0 \\
\hline
\end{tabular}

Berdasarkan Tabel 4 di atas, hasil uji produk permen kesehatan/permen fungsional hasil percobaan dapat diketahui bahwa kelima model percobaan pembuatan permen kesehatan menghasilkan kemampuan daya hambat dan daya bunuh terhadap bakteri Streptoccocusmutans, sama dengan permen kesehatan umumnya. Pada penambahan konsentrasi minyak temulawak $0,40 \%$ pertumbuhan bakteri Streptococcus mutans terhenti pada menit ketiga, pada konsentrasi $0,55 \%$ dan $0,70 \%$ pertumbuhan bakteri terhenti pada menit kedua dan pada konsentrasi $0,85 \%$ dan konsentrasi $1,0 \%$ pertumbuhan bakteri terhenti sejak menit pertama. Ini berarti semakin tinggi konsentrasi minyak temulawak yang ditambahkan pada permen kesehatan hasil percobaan semakin besar kemampuan daya hambatnya dan daya bunuhnya terhadap bakteri Streptococcus mutans. Efektifitas permen kesehatan yang mengandung komponen aktif ekstrak temulawak 
secara in vitro menunjukkan bahwa ada perbedaan nyata dengan efektifitas permen kesehatan reguler yang telah beredar selama ini, dimana permen kesehatan hasil percobaan berpengaruh nyata terhadap kecepatan daya hambat dan daya bunuh terhadap bakteri Streptococcus mutan. Artinya bahan antimikroba yang terkandung dalam permen kesehatan hasil percobaan mempunyai manfaat yang cukup baik untuk digunakan sebagai plak kontrol karena mempunyai aktifitas dengan kemampuan yang kuat. Kemampuan permen kesehatan hasil percobaan yang mempunyai aktifitas kuat karena adanya komponen aktif yang terkandung di dalam minyak temulawak yang diduga senyawa tersebut adalah xanthorrizol. Dengan demikian yang paling bagus untuk pembuatan permen kesehatan adalah minyak temulawak dengan konsentrasi $0,70 \% ; 0,85 \%$ dan $1,0 \%$.

\section{Uji Cita Rasa Permen Kesehatan Secara Hedonik}

Hasil evaluasi uji cita rasa yang dilakukan oleh 15 orang panelis secara uji hedonik terhadap permen kesehatan hasil percobaan berdasarkanlama waktu keberadaan permen kesehatan hasil percobaan di dalam mulut, disajikan pada Tabel 5.

Tabel 5. Hasil nilai (skor) uji hedonik rata-rata 15 panelis terhadap cita rasa permen kesehatan eksperimen berdasarkan lama waktu keberadaan permen kesehatan di dalam mulut.

\begin{tabular}{c|c|c|c|c|c|c}
\hline \multirow{2}{*}{$\begin{array}{c}\text { Permen Kesehatan } \\
\text { Eksperimen }\end{array}$} & \multicolumn{5}{|c}{$\begin{array}{c}\text { Nilai (skor) Uji Hedonik } \\
\text { Rata-Rata Panelis }\end{array}$} \\
\cline { 2 - 7 } & 0,5 menit & 1 menit & 1,5 menit & 2 menit & 2,5 menit & 3 menit \\
\hline A $(0,40 \%)$ & 3,5 & 3,8 & 3,4 & 2,9 & 2,5 & 2,3 \\
\hline B (0,55\%) & 3,6 & 3,7 & 3,6 & 3,0 & 2,8 & 2,5 \\
\hline C (0,70\%) & 3,9 & 4,0 & 3,1 & 2,6 & 2,4 & 2,4 \\
\hline D (0,85\%) & 4,1 & 4,3 & 3,5 & 3,2 & 2,7 & 2,4 \\
\hline E (1,0\%) & 3,7 & 3,9 & 3,2 & 2,5 & 2,3 & 2,1 \\
\hline
\end{tabular}

Dari Tabel 5 di atas dapat dilihat bahwa nilai (skor) uji hedonik rata-rata 15 orang panelis terhadap citarasa dan tingkat kesukaan panelis terhadap permen kesehatan hasil percobaan selama waktu keberadaannya di dalam mulut, cenderung disukai dan naik hingga waktu 1 menit dan setelah itu kembali menurun selama waktu keberadaan permen kesehatan tersebut di dalam mulut para panelis. Hasil analisis sidik ragam pada taraf kepercayaan $a=0,05$ terhadap tingkat kesukaan panelis terhadap citarasa permen kesehatan hasil percobaan selama waktu berada di dalam mulut panelis menunjukkan bahwa citarasa permen kesehatan hasil percobaan untuk semua jenis berbeda nyata untuk perlakuan konsentrasi minyak temulawak yang ditambahkan dan lama waktu permen kesehatan tersebut berada di dalam mulut para panelis. Hasil uji lanjutan BNJ terhadap citarasa pemen kesehatan selama waktu berada di dalam mulut panelis menunjukkan bahwa citarasa permen kesehatan berkode $D$ berbeda nyata permen kesehatan berkode (A, B, C dan E), sedangkan permen kesehatan berkode $C$ tidak berbeda nyata dengan permen kesehatan berkode (A, B, dan $E$ ).

Berdasarkan uji hedonik terhadap citarasa dan tingkat kesukaan panelis terhadap permen kesehatan untuk semua perlakuan selama waktu keberadaan permen kesehatan di dalam mulut para panelis menunjukkan bahwa 
lama waktu keberadaan permen di dalam mulut para panelis berpengaruh terhadap penilaian panelis pada taraf kepercayaan $a=0,05$. Semakin lama permen kesehatan hasil percobaan di dalam mulut, maka nilai (skor) hedonik secara rata-rata akan semakin menurun. Penurunan penilaian panelis terhadap citarasa permen kesehatan terjadi akibat rasa permen kesehatan sudah mengalami penurunan mutu dari segi rasa atau permen tersebut sudah agak pahit dikonsumsi seiring dengan lamanya waktu keberadaan permen kesehatan di dalam mulut para panelis. Kesukaaan panelis terhadap rasa permen kesehatan menunjukkan bahwa secara umum rasa permen kesehatan dapat diterima oleh panelis pada kisaran waktu keberadaan permen kesehatan di dalam mulut antara 0,5 menit sampai dengan 1,5 menit dan panelis memberikan nilai (skor) lebih dari 3 (netral/tidak menolak).

\section{KESIMPULAN}

Kandungan senyawa aktif yang terdapat di dalam minyak temulawak hasil ekstraksi dari rimpang temulawak berdasarkan spektrofometer FT-IR adalah xanthorrizol.

Senyawa aktif xanthorrizol mempunyai kemampuan untuk menghambat bakteri Streptococcus mutans dengan diameter zona daya hambat yang terbesar 16,96\% (konsentrasi 1\%), dikategorikan mempunyai daya hambat antibakteri yang kuat.

Konsentrasi hambat minimal terhadap bakteri Streptoccus mutan sadalah $0,25 \%$ namun konsentrasi tersebut tidak dapat membunuh atau menghentikan aktivitas bakteri. Sedangkan konsentrasi bunuh minimal terhadap bakteri Streptococcus mutans adalah $0,40 \%$.

Permen kesehatan hasil percobaan yang terbaik dari hasil penelitian ini adalah permen kesehatan dengan konsentrasi minyak temulawak sebesar $0,85 \%$ yang dengan cepat menghambat aktivitas bakteri (bersifat bakteristatik) maupun membunuh bakteri Streptococcus mutans (bersifat bakterisidal) dalam waktu 0,5 menit. Permen kesehatan hasil percobaan tersebut oleh panelis memberikan nilai lebih dari 3 (netral/tidak menolak) bahkan nilai 4 (suka).

\section{DAFTAR PUSTAKA}

Allen D. 2004. Oral Hygiene Available from

http://www.Dentarometoothpaste -an all natural alternative.htm. Diakses September 2009.

Amos, 2009.Pemanfaatan Gambir Sebagai Antibakteri Dalam Pembuatan Pasta Gigi.Jurnal Dinamika Penelitian BIPA Vol. 20 No. 36. Hal 41-49

Ardiansyah, 2007, Antimikroba dari Tumbuhan (Bagian Pertama), httpwww. beritaiptek.comzberitaberitaiptek-2007-06-03-

Antimikroba-dari-Tumbuhan(Bagian

Pertama).shtml.htm.Diakses tanggal 11 April 2008.

Ayu, K.C, 2004, Studi Aktivitas Antioksidan dan Antibakteri Pada 10 Merk The Hijau yang Beredar Di Pasaran Kota Malang, Skripsi Mahasiswa JurusanTeknologi Hasil Pertanian, Fakultas Teknologi pertanian, UniversitasBrawijaya,Malang

Cheong, W.J., Park, M.H., Kang, G.W., Ko, J.H., and Seo, Y.J., 2005, Determination of Catechin Compounds in Korea Green Tea InflusionsUnder Various Extraction Conditions by High Performance LiquidChromatography, Departement of Chemistry And Institute of Basic Reserch, Inha University, Bull.Korea Chem.Sec.2005, Vol.26,No.5.

Depkes RI. 1989. Vademekum Bahan Obat Alam. Depkes RI. Dirjen POM. Jakarta : 56. Dewan Standardisasi Nasional. 1995. 
Pasta gigi Dewan Standarrisasi Nasional, Jakarta.

Estrela C, Pecora JDJ, Souza-Neto MD, Estrela CR, Bammann LL. 2001. Effect of Vehicle on Antimicrobial Properties of Calcium Hydroxide Pastes.Braz Dent J, 10 (2) : 6372.

Fardiaz, S. 1992. Mikrobiologi Pangan 1. Gramedia Pustaka Utama, Jakarta.

Hwang, J, K. 2000. Challenges and Opportunities in Applying Temulawak (Curcuma XanthorrizaRoxb) for Industrial Oral Care Products., (Online),(jkhwang@yonsei.ac.kr., diakses September 2008).

Ma'mun , Buletin Balitro Vol. XVII, No. 2, 2006

Pratten, J., K. Wills, P. Barnett, dan M. Wilson. 1998. In Vitro Studies of The Effect of AntisepticContaining Mouthwashes on The Formation and Viability of Streptococcus sanguis Biofilms. Journal of Applied Microbiology $84: 1149-1155$.

Purnomowati, Sri. 2009. Khasiat Temulawak (Online),(www.google.com).Diak ses 3 Maret 2009.

Sartini, Djide N. M, Alam G, 2007. Ekstraksi Komponen Bioaktif dari Limbah Kulit Buah Kakao dan Pengaruhnya Terhadap Aktivitas
Antioksidan dan Antimikroba. JurnalFalkultas Farmasi. Unhas. Hal 1-6

Setiyowati, V., 2007, Karakterisasi dan Pengujian Aktivitas AntiokisdanTabelt Effervescent Ekstrak Teh Hijau Pada Lama Ekstraksi dan Jenis Bahan Pengisi yang Berbeda, Skripsi Mahasiswa Jurusan Teknologi HasilPertanian, Fakultas Teknologi Pertanian, Universitas Brawijaya.

Sidik (2006).Gerakan Nasional Minum Temulawak (Online), (http://www.majalahfarmacia.com., diakses 13 Januari 2009).

Sugandi dan Sugiarto. 1993 Rancangan Percobaan Teori dan Aplikasi. Andi Offset. Yogyakarta.

Suryatmi, D.R. 2008. Kajian Minyak Temulawak Dari Tawangmangu. Disampaikan Pada Konferensi Nasional Minyak Atsiri di hotel singgasana, Surabaya 2-4 Desember.Dit Industri Kimia dan Bagunan, Ditjen IKM, Depperin.

Widiastuti, D, 2005, Sintesis Senyawa 2(4-metilsikloheks-3-enil) propan2-oldari -pinena dan Uji Aktivitasnya Sebagai Antibakteri, Skripsi JurusanKimia Fakultas MIPA, Universitas Brawijaya 